\title{
Adaptations of Australian Tree Species Relevant to Water Scarcity in the Urban Forest
}

\author{
G.M. Moore
}

\begin{abstract}
Water is a valuable resource, but its preferred use by society for other, higher priorities has resulted in a scarcity for the urban forest. However, the value of the urban forest in providing environmental and ecological services that have significant benefits for human health, well-being, and the liveability of cities demands the reconsideration of the priority of water use by the urban forest. Health authorities are advocating the value of urban greenspace that may require the use of water, especially storm water, as climate change threatens more severe heatwaves.

Trees have an important and long-term role in water-sensitive urban design that efficiently uses and reduces pollution from storm water. Knowledge of tree root systems and their interaction with soils means that irrigation can be targeted in a way that maximizes the efficient and effective use of water. Understanding stomatal behavior also allows optimal timing of irrigation for photosynthetic efficiency while capturing the benefits of transpirational cooling, which may reduce extra deaths during heat waves. The economic, social, and health benefits justify the efficient and effective use of valuable water.

Key Words. Australia; Drought; Foliage; Root Adaptation; Urban Water Use.
\end{abstract}

Recently, much of the east coast of Australia was gripped with a prolonged period of lower than average rainfall. The State of Victoria had entered its fourteenth consecutive year of below-average rainfall (Bureau of Meteorology 2011). Since then, there has been record rainfall and flooding in much of the region, and the media have reported the general relief that the drought had finally broken.

The dry period may have been a drought and part of natural cycles of perhaps five hundred years or more, but current meteorological data are too recent to reveal such patterns. However, the dry period, recent major storm events, changes in rainfall patterns, and summer flooding are consistent with predictions made over the past two decades in relation to climate change. It is too early to trumpet the end of the dry period-one season of above-average rainfall should not obliterate the trend of the previous fourteen years.

So the focus on water scarcity, availability, and the efficiency of water use in the urban forest is timely and of great urgency in the context of the Australian environment and climate change more generally. However, is there really a scarcity of water for the urban forest? In cities as diverse as Melbourne, Victoria, and Perth, Western Australia, Australia, only about $8 \%-9 \%$ of the available potable water is used for general open space purposes. This includes both public and private (back and front gardens) open space, and even less water is allocated to trees in the urban forest (Victorian Department of Sustainability and Environment 2006; Victorian Department of Sustainability and Environment 2007).

Furthermore, 10 years ago, gardens, parks, and sporting ovals consumed about $12 \%$ of the State of Victoria's water. Now it is less than $9 \%$. This is a $25 \%$ reduction, and the Law of Diminishing Returns suggests that having made significant sav- ings in water, no matter how much one tries, they are unlikely to get more significant savings from parks, gardens, and the urban forest (Water Resources Strategy Committee 2002; Victorian Department of Sustainability and Environment 2004; Victorian Department of Sustainability and Environment 2007).

Water is a precious commodity, but it is only scarce because other priorities for its use are seen as being more important than open space and the urban forest. No one would deny that the first priority for potable water is to meet the drinking and health needs of citizens. However, in every State, the greatest users of water by far rest in industry and agriculture (Victorian Department of Sustainability and Environment 2004; Victorian Department of Sustainability and Environment 2007). No one would suggest that the urban forest should be irrigated at the expense of drinking water or at a cost to human health or life. The issue is about using a valuable resource sustainably and effectively to capture maximum benefits, including environmental benefits (Nowak et al. 2010). Research must inform the management practices that are required to maintain the urban forest, using water effectively, efficiently, economically, and sustainably.

THE PRIORITY FOR WATER AND THE URBAN FOREST While urban forests are beautiful and decorative, these attributes often conceal the many functions and services that they provide to cities to the point where their social, health, economic, and environmental benefits are overlooked (McPherson 2007; Moore 2009; Nowak et al. 2010). What else delivers so many benefits immediately, and benefits that last centuries into the future, prolonging healthy lives and making cities both sustainable and liveable? Urban forests have been 
silent assets to cities for decades and even centuries. They are major and essential urban infrastructure (Daniels and Tait 2005).

Cities are biodiversity hot spots due to the variety of habitats available in public and private open space, especially the diversity of plantings in domestic front and back yards (Daniels and Tait 2005). The requirement for tree managers is to establish a priority for the urban forest in the allocation of a precious and valuable, rather than scarce, commodity (Connellan 2008). Society will allocate water to items for which there is an economic and political imperative.

For most of its history, the price of water in Australia has been subsidized, however, it does have a real economic value and in most States increasing water prices are moving toward that value (Victorian Department of Sustainability and Environment 2004; Victorian Department of Sustainability and Environment 2006; Victorian Department of Sustainability and Environment 2007). To maintain the urban forest, water must be used effectively and efficiently. There can be no going back to the days of profligate water use and year-round emerald green lawns (Moore 2009). The environment and economy cannot sustain such an approach (Water Resources Strategy Committee 2002). How well informed are the practices governing the use of water in the urban forest and what are the research needs that would enhance best management practices?

\section{ADAPTATIONS RELEVANT TO WATER STRESS}

Trees in the urban forest face the dilemma of all terrestrial plants: the need to balance the interaction of carbon and wa- ter cycles to allow survival and growth. If water is limited and stomata close, carbon assimilation through photosynthesis is reduced (Cowan 1981; Curran et al. 2009; Martin St. Paul et al. 2012). Thus in the urban environment, restricting water availability to trees in the urban forest may also restrict the benefits that they provide, such as their capacity for carbon sequestration (Jonson and Freudenberger 2011) and transpirational cooling.

The performance of different trees species in minimizing water loss, but at the same time maintaining carbon dioxide gain, is defined as water-use efficiency:

\section{Water-use efficiency}

$$
\text { Carbon gained }
$$

The value of water use efficiency varies for different species and can be used to select trees that are more productive for use in cities of drier climates (Ladiges et al. 2005).

Australian tree species possess many and varied adaptations to growing in arid environments (Table 1). One of the defining characteristics of many Australian plant genera is sclerophylly. Sclerophyllous trees possess large amounts of sclerenchyma tissue, which maintains cellular volume as conditions dry. It is often assumed that sclerophylls are low water users, but paradoxically many have poor stomatal control and will use whatever water is available until they wilt (Ladiges et al. 2005). Many have the capacity to survive in environments where water is limited, and managers could proactively minimize the supply of water in low-water environments using sclerophyllous trees.

Table 1. Adaptations of Australian tree species to aridity (Ashton 1975; Moore 1981; Pate and McComb 1981; New 1984; Moore 1990; Knox et al. 1994; King 1997; Atwell et al. 1999; Ladiges et al. 2005).

\begin{tabular}{|c|c|c|}
\hline Adaptation & Mechanism & Examples \\
\hline Sclerophylly & Maintains cellular volume & $\begin{array}{l}\text { Many Australian genera, such as Acacia, and members } \\
\text { of the Proteaceae and Myrtaceae families }\end{array}$ \\
\hline Altered leaf anatomy & Reduces leaf surface area & Hakea and Acacia species with rolled needle like leaves \\
\hline Phyllodes/cladodes & Reduces surface area; reduces evapotranspiration & Most Australian Acacia species \\
\hline Vertically hanging leaves & Reduces absorption of radiation & Many eucalypt species \\
\hline Leaf/pinnule movement & Reduces exposed leaf surface area & Bi-pinnate Acacia species; Lophostemon confertus \\
\hline Cuticular adornment & Reduces evapotranspiration & $\begin{array}{l}\text { Many genera, such as Eucalyptus, Acacia, and } \\
\text { Casuarina, with hairy, spiny, or glaucous leaves }\end{array}$ \\
\hline Stomatal crypts & Reduces evapotranspiration & Banksia species, Hakea species \\
\hline Cuticular ledges & Reduces evapotranspiration & Eucalyptus preissiana, E. obliqua \\
\hline $\begin{array}{l}\text { Stomatal closure in response } \\
\text { to atmospheric vapor deficit }\end{array}$ & Reduces transpirational water loss & $\begin{array}{l}\text { Eremophila macgillivrayi, Myoporum floribundum, } \\
\text { Myoporum platycarpum, Pittosporum phylliraeoides, } \\
\text { Geijera parviflora }\end{array}$ \\
\hline Facultative deciduousness & $\begin{array}{l}\text { Reduces growth but allows survival over } \\
\text { tropical dry period }\end{array}$ & $\begin{array}{l}\text { Some Blakella eucalypts, such as E. clavigera, } \\
\text { E. grandiflora, and E. brachyandra }\end{array}$ \\
\hline Lignotubers/basal burls & Rapid regrowth after foliage loss & Most eucalypts; Acmena smithii \\
\hline Epicormic buds & Rapid regrowth after foliage loss & Most eucalypts \\
\hline Deep tap root & Allows access to deeper soil water profile & E. camaldulensis \\
\hline High root:shoot ratio & Increases soil volume accessed for water supply & E. camaldulensis \\
\hline
\end{tabular}


The leaves and phyllodes of many Australian species (Table 1) are isobilateral and often hang vertically, thereby reducing the surface area that is exposed to the sun (King 1997). Species such as Eucalyptus preissiana (Knox et al. 1994) and E. obliqua have prominent cuticular ledges, which overarch their stomata, creating a stomatal antechamber that reduces transpirational water loss (Moore 1981). However, the stomatal anatomy of many common street trees species remains unknown.

In Australian tree species, the number of stomata ranges from about $28 \mathrm{~mm}^{-2}$ in Persoonia (geebung) to between 100-350 per $\mathrm{mm}^{2}$ in eucalypts. The number often varies inversely with size with fewer larger stomata contrasting many smaller stomata (Knox et al. 1994). In Eucalyptus globulus, there are 300 stomata $\mathrm{mm}^{-2}$, but the leaf area occupied by stomatal apertures is only about $1 \%$. However, with stomata open, the rate of transpirational water loss is the same as for evaporation from an open wet surface; water and gaseous movement through open stomata is remarkably efficient. Thus, knowledge of stomatal rhythms and behavior is essential to understanding tree water use and survival in water-limited environments.

Trees such as Casuarina littoralis, Eucalyptus calophylla, Eremophila macgillivrayi, Pittosporum phylliraeoides, and Myoporum floribundum show effective stomatal control and so more efficient wateruse, but if water is limited then their growth rates may be slowed to the point where they are ineffective for planting in the urban forest. Similarly, species such as Acacia melanoxylon or Eucalyptus grandiflora, which reduce water use through reduction in leaf surface area, may lack the canopy characteristics and density that would make them attractive for urban forest planting.

For most Australian tree species planted in urban environments there are almost no data on basic physiological processes, such as stomatal behavior, let alone whether they are stress avoiders or tolerators in relation to water (Table 2). Which trees have good stomatal control as soil moisture diminishes (Eamus et al. 2001; Prior et al. 2005), which keep their stomata open and so are luxury water-users, and which species can tolerate low internal water potentials are largely un- known (Atwell et al. 1999), except for those few species that are of interest for forestry, timber, or agricultural research (Pate and McComb 1981; Meier and Leuschner 2008). Such basic research would not take large amounts of funding, and simple data gathering using basic porometry would not take long, but this has not attracted the interest of the research funding bodies.

Acacia is Australia's largest indigenous genus with over 900 woody species ranging from shrubs to large trees. They are generally sclerophyllous and Australian species are typically phyllodenous in contrast to the Acacia species of Africa and South America (Thukten 2006). Many arid zone Acacia species are known for their extreme avoidance of desiccation (New 1984; Broadhurst and Young 2006; Page et al. 2011). While A. harpophylla is more drought resistant than A. aneura, even the latter has phyllodes that can lose a large proportion of their water content without harm.

Many species maintain cell turgor despite high levels of moisture stress. In some species, phyllode size reduces in drier areas (Thukten 2006; Deines et al. 2011). The size and shape of A. melanoxylon phyllodes are affected by both aridity and seasonal rainfallpatterns(FarrellandAshton 1978). SeveralAcacia species have very deep roots that may reach depths of $12 \mathrm{~m}$ or more (Table 2). A. mearnsii may have roots that penetrate to $6 \mathrm{~m}$, but $75 \%$ of the root system is within $600 \mathrm{~mm}$ of the soil surface.

The closure of pinnules as soils dry is easily observed in A. mearnsii-a bi-pinnate leafed species-growing in the basaltic clays of the western plains near Melbourne. This reduces transpirational water loss. In plantations, A. mearnsii could lose $261 \mathrm{~kg}$ of water per day compared to A. decurrens' $44 \mathrm{~kg}$, but this was largely due to a difference in foliage density with $A$. mearnsii having a foliage mass of $69 \mathrm{~kg}$, while A. decurrens had a foliage mass of $9 \mathrm{~kg}$ (New 1984). In an urban forest, a choice between these species may come down to a decision about canopy appearance, density and impact versus water use.

There are major research gaps in the use of Australian native species, as well as exotic species, growing under Australian environmental conditions. Few studies are available on water use by

Table 2. Avoidance and Tolerance Mechanisms for coping with low water environments.

\begin{tabular}{|c|c|c|c|}
\hline Strategy & Mechanism(s) & Growth & Examples \\
\hline Drought avoidance & $\begin{array}{l}\text { Grow where and when water } \\
\text { is available }\end{array}$ & $\begin{array}{l}\text { Unaffected until water is } \\
\text { limiting }\end{array}$ & $\begin{array}{l}\text { Eucalyptus regnans, E. camaldulensis, } \\
\text { E. marginata }\end{array}$ \\
\hline & Increased root density & Improved & E. camaldulensis, Acacia mearnsii \\
\hline & Good stomatal control & Usually reduced & $\begin{array}{l}\text { Casuarina littoralis, E. calophylla, } \\
\text { Eremophila macgillivrayi, Pittosporum } \\
\text { phylliraeoides, Myoporum floribundum }\end{array}$ \\
\hline & Capacity for osmotic adjustment & Usually reduced & Atriplex nummularia, E. viminalis \\
\hline & Reduced leaf surface area & Usually reduced & $\begin{array}{l}\text { Acacia melanoxylon, Acacia mearnsii, } \\
\text { E. clavigera, E. grandiflora, } \\
\text { E. brachyandra }\end{array}$ \\
\hline & Larger root:shoot ratio & Usually reduced & $\begin{array}{l}\text { E. camaldulensis, E. marginata, } \\
\text { Acacia mearnsii }\end{array}$ \\
\hline $\begin{array}{l}\text { Drought tolerance by } \\
\text { maintaining cell volume }\end{array}$ & More elastic cell walls & Usually reduced & Acacia aneura \\
\hline Dehydration tolerance & $\begin{array}{l}\text { Cells and physiology unaffected } \\
\text { by reduced water content }\end{array}$ & Usually reduced or restricted & $\begin{array}{l}\text { E. rossii, E. viminalis, } \\
\text { Acacia aneura }\end{array}$ \\
\hline
\end{tabular}

Note: Columns 1-3 of this table are extended and modified from Atwell et al. 1999. Column 4 is based on the author's experience with these Australian species. 
Table 3. Australian Tree species with full or facultative deciduousness, usually in response to a dry period (Australian Plant Study Group 1980; Francis 1981; Boland et al. 1984; Snape 2002).

\begin{tabular}{|c|c|c|c|}
\hline Species & Common name & Species & Common name \\
\hline Brachychiton rupestris & bottle tree & Gmelina leichhardtii & white beech \\
\hline Brachychiton discolor & lacebark tree & Lysiphyllum cunninghamii & native bauhinia \\
\hline Brachychiton bidwillii & rusty kurrajong & Lysiphyllum carroni & native bauhinia \\
\hline Ehretia acuminata & koda & Nauclea orientalis & leichhardt tree \\
\hline Erythrina vespertilio & bat wing tree & Peltophorum pterocarpum & yellow poinciana \\
\hline Ficus superba & deciduous fig & Sterculia quadrifida & peanut tree \\
\hline Ficus virens & white fig & Terminalia catappa & sea almond \\
\hline Ficus fraseri & sandpaper fig & Toona australis & red cedar \\
\hline
\end{tabular}

urban trees growing within the urban environment(Misra and Sands 1993), despite an urgent need by tree and water resource managers for quantification (Connellan 2008). There are better data on the irrigation required for establishing young trees (May 2004).

Drought avoiders such as E. camaldulensis, E. regnans, and $E$. marginata are profligate luxury water-users that will grow rapidly and use significant volumes of water if it is available. They may be inappropriate for urban use where water is limited in supply or costly, while proving ideal for places where water is abundant or as part of water-sensitive urban design measures to control local flooding by holding and absorbing water during more intense rainfall events predicted under a changed climate (Killicoat et al. 2002; Moore 2009). The economic value of reducing localized flooding could be substantial (Moore 2009). Research shows trees to be effective in removing pollutants, such as nitrogen and phosphorus, from stormwater run-off (Denman 2006), and may prove to be useful, long-term elements of water-sensitive urban design.

Many tree species also possess physiological, anatomical, and morphological adaptations to growing in arid conditions (Kursar et al. 2009). Many eucalypt species seem to remain physiologically active, using water under conditions of moderate to severe water stress, reflecting their mesophytic evolutionary origins. However, not all eucalypts are equal in their capacity to cope with dry conditions. In Western Australia, E. calophylla has better stomatal control than E. marginata, which is a luxury water-user. Similarly, in eastern Australia, E. regnans is a profligate water-user with little capacity for stomatal control, while E. obliqua behaves similarly to E. calophylla.

It is interesting to compare a hypothetical scenario where Pinus radiata and Eucalyptus rossii are planted in the same, low phosphorus Australian soil in an urban streetscape where rainfall is low and there is no irrigation after the first year of establishment. When soil water potential falls, the $P$. radiata closes stomata, reducing photosynthetic assimilation and growth. The E. rossii on the other hand keeps stomata open and tolerates a decline in internal water potential. When occasional light rain falls, the E. rossii resumes photosynthetic assimilation immediately and commences growth (Florence 1981). The P. radiata does not open its stomata and the soil dries, perhaps compounded by the opportunistic uptake of water by E. rossii. The E. rossii out grows and out competes the $P$. radiata under this scenario.

Winter deciduous Australian native trees are relatively rare, with Melia azedarach, Nothofagus gunnii, and Brachychiton acerifolius being notable examples. Furthermore a few northern species, including some eucalypts, such as E. clavigera, E. grandiflora, and E. brachyandra, are facultatively deciduous during the dry period (Williams et al. 1997). This characteristic is shared with a number of other tree species, some of which are suit- able for urban use (Table 3). However, there has been very little breeding and selection of these native species for urban use, and even less research on whether breeding might allow deciduousness to apply to southern winters, expanding the potential use of any of these or related species (Munne-Bosch and Alegre 2004).

Some species have stomata that respond to the vapor pressure of the ambient air (Table 1). Stomata close in response to drier air and leaf moisture content increases as a result, but transpiration reduces accordingly. Species with this characteristic could prove very useful in cities where water is limited, but while the response has been observed in some species with potential for urban use, it is largely unresearched.

Some species of Australian urban trees come from populations that have wide and extensive natural distributions in environments where water availability varies (Wheeler et al. 2003). There are good data to inform provenance selections for many forest species (Hamrick 2004; Broadmeadow et al. 2005; Craft and Ashley 2007; Gouveia and Freitas 2009), but arboricultural data on Australian species of amenity trees are not so easily accessed. Studies on provenances of Lophostemon confertus (Williams 1996) and Tristaniopsis laurina (Looker 2001), from different climate and soil conditions, have been undertaken and would allow urban selections for drier climates. Even if species' ranges are limited, there may be the option of selecting different species from within a genus. This is the case with the genera Eucalyptus and Acacia within Australia, where there are large numbers of related species occupying a broad range of habitats.

Often in eucalypt-dominated forests it is common for different species to occupy environments that become increasingly drier (Fensham and Holman 1999). This gives rise to the concept of a displacement series, of often-related species, which replace each other over an ecotone of increasingly arid environments (Pate and McComb 1981; Shepherd et al. 2008; Holman et al. 2011). As this happens, species have a tendency to show characteristics (Table 4) that better adapt them to the drier conditions. These characteristics could be used by urban forest managers as a guide for what species might be successful for urban planting in drier conditions, but very little research has been applied to the urban context.

Good Australian data support the use of irrigation under singular mulches in general, and mixed particle size organic mulches in particular (Connellan et al. 2000; Handreck and Black 2002). Early morning subsurface irrigation regimes that permit trees to open stomata early to maximize photosynthesis before water becomes limiting are based on sound tree physiology. In many species, stomata are often closed by about 2:00 pm, especially if soil water is limiting (Eamus 2006). Furthermore, for many tree 
species evapotranspiration cools them, reducing the risks of heat damage, especially on hot windy days, the frequency of which is likely to increase under climate change. Such irrigation also captures at least some of the general and environmental benefits that the urban forest provides in terms of transpirational cooling.

Table 4. Characteristics of a eucalypt displacement series from wetter to drier environments (Pate and McComb 1981).

Characteristic altered as environment dries

- Greater root:shoot ratio

- Increasing root:shoot ratio in response to water stress

- Slower stomatal response to decreasing xylem water potential

- Slower decline in leaf turgidity with increased water stress

- Lower rate of transpiration in wetter soils

\section{ROOT ARCHITECTURE AND WATER USE}

When a tree seed germinates in natural soils, the radicle emerges and usually develops into a tap root. In Australian native tree species, such as Eucalyptus and Acacia, it is not uncommon to find a seedling of $20 \mathrm{~mm}$ height with a primary root of 150-200 mm in length (Moore 2008). This root then rapidly develops as a tap root, anchoring the young tree, providing necessary water and nutrients and the framework from which lateral roots develop (Awe et al. 1976). In most urban trees, however, the tap root should be considered a juvenile characteristic, which only persists for the early establishment phase of the tree's life cycle (Ashton 1975; Moore 1990).

The root systems of mature trees have a tendency to be spreading and relatively shallow (Watson and Neely 1994). The typical urban forest tree root system consists of a shallow spreading root plate of lateral spreading roots complemented by the presence of descending (or vertical or sinker) roots, which usually occur around the base of the tree or close to the trunk, where oxygen is more readily available and where nutrients and organic matter are being actively recycled (Coile 1937; Perry 1982). While the lateral roots are often within $200-300 \mathrm{~mm}$ of the soil surface, descending roots may grow to depths of $1000 \mathrm{~mm}$ or more. There are also descending roots farther out along the root plate, which have a tendency to be smaller in diameter and shallower in their descent. These roots may persist for a number of years before they die back and are replaced (Moore 1995; Smith and Moore 1997).

This common pattern of urban tree root architecture has profound implications for the application of water. However, there are few data on the variations in root architecture for native and exotic trees and almost none comparing Australian native species. Many irrigation regimes assume that roots are close to the trunk and under the drip line of canopies. This seems to be the case for species such as elms, but is not necessarily the case for eucalypts and other species where exposure of root systems with an air knife shows the presence of major structural roots within the drip line but very few, if any, fine absorbing roots (Moore 2008). The absorbing roots are often $10 \mathrm{~m}$ or more from the trunk and concentrated where moisture levels are higher.

There is an urgent need for data on the root architecture of Australian urban tree species. It is vital to know where roots are, why they develop where they do, and how much water they are capable of removing from soil in their vicinity. It is also essential to know where, and at what depth, water should be supplied for efficient and effective irrigation (Connellan 2008). There is a popular view that trees absorb water from deep in the soil profile and that only "deep soaking" is effective irrigation over summer. Current knowledge of root architecture suggests that this is not the case for urban forest trees, but there is little research to inform the debate. Consequently, water restrictions that limit irrigation of urban trees have been imposed rather than allowing an occasional irrigation of the absorbing root plate near the soil surface. This has resulted in higher levels of stress and the deaths of many mature trees in the urban forest over the past decade.

\section{CONCLUSION}

There has been great public interest in efficient and effective water use and conservation. However, the debate has often been fuelled by anecdotal information rather than being informed by data on water use by different plant species. There have been debates about whether trees-native or exotic-should be irrigated over the summer, and suggestions that perhaps nature should take its course and trees left to die. In many parts of southeastern Australia, restrictions to water use have been applied to gardens, parks, and streetscapes without data to support the impositions. Does restricting irrigation actually save water, and what are the consequences of the restrictions on trees and society as a whole? It has been argued that the use of water during days of extreme high temperatures could reduce ambient temperatures by both surface evaporation and transpirational cooling (Nicholls et al. 2008; Loughnan et al. 2010), thereby reducing the number of excess human deaths that occur during heat waves.

Australia's major cities are not only urban forests but biodiversity hot spots (Daniels and Tait 2005). The parks, gardens, streets, and front and backyards constitute an urban forest that is very diverse in its range of species that generate myriad habitats and niches. High-density urban developments and inner city renewal make it virtually impossible to grow trees in places that were once green and leafy. Water scarcity is exacerbating the loss of urban vegetation cover, but there are many alternate planting options available to urban tree managers, if they are prepared to use the data that are available, largely from forestry research, on the root, foliage, and physiological adaptations of many Australian trees species to arid environments. There is an urgent need to obtain similar data for tree species commonly planted in urban environments. The costs of such research would be more than offset by improved water use efficiency and the benefits that effectively managed urban forests provide.

At a time of climate change, it is concerning that trees in the urban forest-in both private and public open spaces-are threatened by a scarcity of water that is not just imposed by rainfall decreases and climate change but by water restrictions as well. Water is a valuable commodity in limited supply, but by using the knowledge and data provided by research on the adaptations that many Australian trees have to water stress, much can be done in selecting and managing tree species for use in the urban forest that will allow amelioration of the heat island effect, reduction in wind speed, provision of shade, and reduction in energy use. Such outcomes should ensure enhanced economic viability, capture the health and social benefits that trees in the urban forest provide, and offer valuable green infrastructure that will contribute to the long-term sustainability of cities. 


\section{LITERATURE CITED}

Ashton, D.H. 1975. The root and shoot development of Eucalyptus regnans $\mathrm{F}$ Muell. Australian Journal of Botany 23:867-887.

Atwell, B., P. Kriedemann, and C. Turnbull. 1999. Plants in Action. MacMillan, Australia.

Australian Plant Study Group. 1980. Grow What Where. Nelson, Melbourne.

Awe, J.G., K.R. Shepherd, and R.G. Florence. 1976. Root development in provenances of Eucalyptus camaldulensis Dehn. Australian Forestry 39:201-209.

Boland D.J., M.I.H. Brooker, G.M. Chippendale, N. Hall, B.P.M. Hyland, R.D. Johnston, D.A. Kleinig, and J.D. Turner. 1984. Forest Trees of Australia. Nelson-CSIRO, Melbourne.

Broadhurst, L.M., and A.G. Young. 2006. Reproductive constraints to the long-term persistence of fragmented Acacia dealbata (Mimosaceae) populations in southeast Australia. Biological Conservation 133:512-526.

Broadmeadow, M.S.J., D. Ray, and C.J.A. Samuel. 2005. Climate change and the future of broadleaved tree species in Britain. Forestry 78:145-161.

Bureau of Meteorology. 2011. Monthly Rainfall, Melbourne Airport, 1971-2010, Australian Government.

Coile, T.S. 1937. Distribution of forest tree roots in North Carolina piedmont soils. Journal of Forestry 35:247-257.

Connellan, G.J. 2008. Water Management Strategies for Urban Trees in an Uncertain Environment. In: D. Lawry, J. Gardner, and S. Smith (Eds.). Proceedings of the Ninth National Street Tree Symposium, University of Adelaide/Waite Arboretum, Adelaide, Australia.

Connellan, G.J., K. James, and P.B. May. 2000. Developing water management strategies for urban trees using soil moisture sensor technology, Proceedings of ASAE 4th Decennial Irrigation Conference, 14-16 November, 2000. Phoenix, Arizona, U.S.

Cowan, I.R. 1981. Coping with Water Stress. In: J.S. Pate and A.J. McComb (Eds.). The Biology of Australian Plants. University of Western Australia Press.

Craft, K.J., and M.V. Ashley. 2007. Landscape genetic structure of bur oak (Quercus macrocarpa) savannas in Illinois. Forest Ecology and Management 239:13-20.

Curran, T.J., P.J. Clarke, and N.W.M. Warwick. 2009. Water relations of woody plants on contrasting soils during drought: Does edaphic compensation account for dry rainforest distribution? Australian Journal of Botany 57:629-639.

Daniels, C.B., and C.J. Tait (Eds.). 2005. Adelaide - Nature of a city: The ecology of a dynamic city from 1836 to 2036. BioCity: Centre for Urban Habitats: Adelaide.

Deines, J.M., J.J. Hellmann, and T.J. Curran. 2011. Traits associated with drought survival in three Australian tropical rainforest seedlings. Australian Journal of Botany 59:621-629.

Denman, L., P.F. Breen, and P.B. May. 2006. An investigation of the potential to use street trees and their root zone soils to remove nitrogen from urban stormwater. Australian Journal of Water Resources 10:303-311.

Eamus, D., L. Hutley, and A.P. O'Grady. 2001. Carbon and water fluxes above a north Australian savanna. Tree Physiology 21:977-988.

Farrell, T.P., and D.H. Ashton. 1978. Population Studies of Acacia melanoxylon R.Br. 1 variation in seed and vegetative characteristics. Australian Journal of Botany 26:365-79.

Fensham, R.J., and J.E. Holman. 1999. Temporal and spatial patterns in drought-related tree dieback in Australian savanna. Journal of Applied Ecology 36:1035-1050.
Florence, R.G. 1981. The Biology of the Eucalypt Forest. In: J.S. Pate and A.J. McComb (Eds.). The Biology of Australian Plants, University of Western Australia Press.

Francis, W.D. 1981. Australian Rainforest Trees. Australian Government Publishing Service, Canberra.

Gouveia, A., and H. Freitas. 2009. Modulation of leaf attributes and water use efficiency in Quercus suber along a rainfall gradient. Trees: Structure and Function 23:267-275.

Hamrick, J.L. 2004. Response of forest trees to global environmental changes. Forest Ecology and Management 197:323-335.

Handreck, K., and N. Black. 2002. Growing Media for Ornamental Plants and Turf (3rd edition), UNSWP.

Holman, J.E., J.M. Hughes, and R.J. Fensham. 2011. Origins of a morphological cline between Eucalyptus melanophloia and Eucalyptus whitei. Australian Journal of Botany 59:244-252.

Jonson, J.H., and D. Freudenberger. 2011. Restore and sequester: Estimating biomass in native Australian woodland ecosystems for their carbon-funded restoration. Australian Journal of Botany 59:640-653.

Killicoat. P., E. Puzio, and R. Stringer. 2002. The Economic Value of Trees in Urban Areas: Estimating the Benefits of Adelaide's Street Trees. Proceedings Treenet Symposium, 94-106. University of Adelaide.

King, D.A. 1997. The functional significance of leaf angle in Eucalyptus. Australian Journal of Botany 45:619-639.

Knox, R.B., P. Ladiges, B. Evans, and R. Saint. 1994. Biology: An Australian Focus. McGraw Hill, Ryde, New South Wales, Australia.

Kursar, T.A., B.M.J. Engelbrecht, A. Burke, M.T. Tyree, B.E. Omari, and J.P. Giraldo. 2009. Tolerance to low leaf water status of tropical tree seedlings is related to drought performance and distribution. Functional Ecology 23:93-102.

Ladiges, P., B. Evans, R. Saint, and R.B. Knox. 2005. Biology: An Australian Focus (3rd Edition). McGraw Hill, Ryde, New South Wales.

Looker, M. 2001. Taxonomic and horticultural implications of variation in natural populations of Tristaniopsis laurina. Ph.D. Thesis, Latrobe University, Melbourne, Australia.

Loughnan, M., N. Nicholls, and N. Tapper. 2010. When the heat is on: Threshold temperatures for AMI admissions in Melbourne, Australia. Journal of Applied Geography 30:63-69.

Martin, St. Paul., N.K., J.-M. Limousin J. Rodríguez-Calcerrada, J. Ruffault, S. Rambal, M.G. Letts, and L. Misson. 2012. Photosynthetic sensitivity to drought varies among populations of Quercus ilex along a rainfall gradient. Functional Plant Biology 39:25-37.

May, P.B. 2004. Soils, Water, and Tree Establishment, Proceedings of the Fifth National Street Tree Symposium, University of Adelaide/Waite Arboretum, Adelaide.

McPherson, E.G. 2007. Benefit based tree evaluation. Arboriculture \& Urban Forestry 33:1-11.

Meier, I., and C. Leuschner. 2008. Leaf size and leaf area index in Fagus sylvatica forests: Competing effects of precipitation, temperature, and nitrogen availability. Ecosystems 11:655-669.

Misra, R.K., and R. Sands. 1993. Water extraction by isolated trees and its possible impact on building foundations on clay soils. Australian Journal of Soil Research 31:25-37.

Moore, G.M. 1981. The Effects of High Temperatures on the Growth and Physiology of E. obliqua Seedling, Ph.D. Thesis University of Melbourne, Melbourne, Australia.

Moore, G.M. 1990. Tree Care for the Home Gardener. Lothian, Melbourne. 64 pp. 
Moore, G.M. 1995. Realities of Street Tree Planting in Relation to Built Structures, from Trees in the Urban Environment, RAIPR, Adelaide. $11 \mathrm{pp}$.

Moore, G.M. 2008. Managing Urban Tree Root Systems. In: D. Lawry, J. Gardner, and S. Smith (Eds.). Proceedings of the Ninth National Street Tree Symposium, Appendix 6. 7 pp. University of Adelaide/ Waite Arboretum, Adelaide.

Moore, G.M. 2009 People, Trees, Landscapes and Climate Change. In: H. Sykes (Ed.). Climate Change On for Young and Old, pp. 132-149. Future Leaders, Melbourne.

Munne-Bosch, S., and L. Alegre. 2004. Die and let live: Leaf senescence contributes to plant survival under drought stress. Functional Plant Biology 31:203-216.

Nicholls, N., C. Skinner, M. Loughnan, and N. Tapper. 2008. A simple heat alert system for Melbourne, Australia. International Journal of Biometeorology 52:375-384.

New, T.R. 1984. A biology of Acacias. Oxford University Press. 153 pp. Melbourne, Australia.

Nowak, D.J., S.M. Stein, P.B. Randler, E.J. Greenfield, S.J. Comas, M.A. Carr, and R.J. Alig. 2010. Sustaining America's Urban Trees and Forests, USDA For Serv, Gen Tech Report NRS-62.

Page, G.F.M., L.E. Cullen, S. van Leeuwen, and P.F. Grierson. 2011. Inter- and intra-specific variation in phyllode size and growth form among closely related Mimosaceae Acacia species across a semiarid gradient. Australian Journal of Botany 59:426-439.

Pate, J.S., and A.J. McComb. 1981. The Biology of Australian Plants. University of Western Australia Press.

Perry, T.O. 1982 The ecology of tree roots and the practical significance thereof. Journal of Arboriculture 9:197-211.

Prior, L.D., D.J.J.S. Bowman, and D. Eamus. 2005. Intra-specific variation in leaf attributes of four savanna tree species across a rainfall gradient in tropical Australia. Australian Journal of Botany 53:323-335.

Shepherd, M., S. Kasem, G. Ablett, J. Ochieng, and A. Crawford. 2008. Genetic structuring in the spotted gum complex (genus Corymbia, section Poltaria). Australian Systematic Botany 21:15-25.

Smith, K.D., and G.M. Moore. 1997. Tree Establishment Ecology. In: B.J. Gould (Ed.). Trees in the Urban Landscape, pp. 38-52. New Zealand Arboricultural Association, Auckland, New Zealand.

Snape, D. 2002. The Australian Garden. Bloomings Books, Melbourne, Australia.

Thukten, W.N.W.M. 2006. Water relations of phyllodinous and nonphyllodinous Acacias, with particular reference to osmotic adjustment. Physiologia Plantarum 127:393-403.

Victorian Department of Sustainability and Environment. 2004. Securing our water future together, White Paper, Victorian Government.

Victorian Department of Sustainability and Environment. 2006. Central region sustainable water strategy action to 2055. Victorian Government.

Victorian Department of Sustainability and Environment. 2007. Our water our future: The next stage of the Government's plan, Victorian Government.

Water Resources Strategy Committee. 2002. 21st Century Melbourne: a watersmart City. Water Resources Strategy Committee for the Melbourne Area (Final Report)

Watson, G.W., and D. Neely (Eds.). 1994. The Landscape Below Ground. International Society of Arboriculture, Illinois, U.S.

Wheeler, M.A., M.M. Byrne, and J.A. McComb. 2003. Little genetic differentiation within the dominant forest tree, Eucalytpus marginata (Myrtaceae) of south-western Australia. Silvae Genetica 52:254-259.
Williams, G.S. 1996. Selection of Australian Rainforest Tree Species and Provenances with Superior Tolerance of Urban Conditions. Master of Applied Science (Horticulture) Thesis, Burnley College, University of Melbourne, Melbourne, Australia.

Williams, R.J., B.A. Myers, W.J. Muller, G.A. Duff, and D. Eamus. 1997. Leaf phenology of woody species in a north Australian tropical savanna. Ecology 78:2542-2558.

\section{G.M. Moore}

Senior Research Associate

University of Melbourne, Burnley

500 Yarra Boulevard

Richmond, Australia 3121

Zusammenfassung. Wasser ist eine wertvolle Ressource, aber der bevorzugte Gebrauch durch die Gesellschaft für andere, höhere Prioritäten führte zu einer Verknappung für den urbanen Wald. Dennoch erfordert der Wert urbaner Wälder als Lieferant ökonomischer und ökologischer Dienste, die einen wertvollen Beitrag zur Gesundheit und menschlichen Wohlbefinden und zum Lebenswert der Städte leisten, eine Neuüberlegung der Priorität der Wassernutzung durch urbane Wälder. Die Gesundheitsbehörden unterstützen den Wert von urbanen Grünräumen, die den Verbrauch von Wasser, insbesondere Sturmwasser erfordern, weil Klimawechsel mehr schwere Hitzeperioden verursachen.

Bäume spielen eine wichtige und langfristige Rolle im wasser-sensitiven urbanen Design, welches effizient die Umweltverschmutzung durch Sturmwasser nutzt und reduziert. Die Kenntnis der Wurzelsysteme und ihrer Interaktionen mit dem Boden bedeutet, dass die Bewässerung zielgerichtet werden kann zur Maximierung des effizienten und effektiven Gebrauchs von Wasser. Ein Verständnis des stomatalen Verhaltens erlaubt auch ein optimales timing der Bewässerung für die photosynthetische Effizienz bei gleichzeitiger Gewinnung der Vorteile durch transpirationeller Kühlung, die die zusätzlichen Tode während der Hitzewellen reduzieren können. Die ökonomischen, sozialen und gesundheitlichen Vorteile rechtfertigen einen effizienten und effektiven Gebrauch von wertvollem Wasser.

Resumen. El agua es un recurso valioso, la sociedad da prioridades para su uso, por lo que se ha dado lugar a la escasez para el bosque urbano. Sin embargo, el valor de los bosques urbanos en la prestación de servicios ambientales y ecológicos, que tienen beneficios significativos para la salud humana, el bienestar y la habitabilidad de las ciudades, exige el replanteamiento de la prioridad de uso de agua por el bosque urbano. Las autoridades de salud están defendiendo el valor del espacio verde urbano que puede requerir el uso de agua, especialmente el agua de lluvia, ya que el cambio climático amenaza con olas de calor más severas. Los árboles tienen un papel importante y de largo plazo en el diseño urbano, que utilice eficientemente y reduzca la contaminación de las aguas pluviales. El conocimiento de los sistemas de raíces de los árboles y su interacción con los suelos significa que el riego puede ser más objetivo de manera que maximice el uso eficiente y eficaz del agua. La comprensión del comportamiento estomático también permite la sincronización óptima del riego para la eficiencia fotosintética y la obtención de los beneficios del enfriamiento por transpiración, lo que puede reducir las muertes adicionales durante las olas de calor. Los beneficios económicos, sociales y de salud justifican el uso eficiente y efectivo del valioso recurso hídrico. 